\title{
TRANSECTION OPERATIONS FOR PORTAL HYPERTENSION
}

\author{
BY \\ R. MILNES WALKER \\ From the University of Bristol
}

(RECEIVED FOR PUBLICATION FEBRUARY 24, 1960)

The treatment of bleeding from oesophageal varices has given rise to much discussion during the last decade and a half. There is now no doubt that a wide anastomosis between the portal vein and the inferior vena cava gives results which are much better than any other procedure as a means of reducing the danger of this haemorrhage. If the splenic vein is large an end-to-side splenorenal anastomosis holds out a good prospect of remaining patent, but the risk of its occlusion is greater than in the case of a portacaval anastomosis.

Unfortunately there are many patients who bleed and in whom, for one reason or another, such a wide shunt is not feasible. Clatworthy and Boles (1959) have performed an anastomosis between the superior mesenteric vein and the inferior vena cava after division of the latter in four patients, but in three cases bleeding recurred and in the fourth the shunt was thought to be occluded. In my hands such makeshift shunts have not been satisfactory. Many procedures other than shunts have been recommended. The least in the range is the injection of sclerosing agents into the varices performed through an oesophagoscope (Macbeth, 1955). More extensive operations involve a direct approach to the oesophagus through the left pleural cavity. Thus Boerema (1949) opened the oesophagus by a longitudinal incision and obliterated the varices by multiple sutures, and this method has also been used by Crile (1957) and by Linton and Ellis (1956). Welch (1956) has performed a similar operation by an abdominal approach. Cooley and DeBakey (1954) recommended extensive oesophago-gastric resection, a method first used by Phemister and Humphreys (1947), and also by Macpherson, Owen, and Innes (1956). Merendino and Thomas (1958) have added to this operation by the interposition of a segment of jejunum while Koop and Roddy (1958) have used a portion of the colon in a similar way. Blackburn (1956) described one patient who had fatal bleeding from the intrathoracic part of the jejunum following a resection and oesophagojejunostomy. Allison (1959) in his Joll Lecture reported extensive devascularization of the upper part of the stomach and the lower oesophagus by a combined thoraco-abdominal approach, and Nylander and Turunen (1955) have tried to improve the collateral circulation by the displacement of the spleen into the thoracic cavity.

In 1950 Tanner described an attempt to cut off the whole of the flow of blood from the portal system into the azygos system by an operation which he called "portal azygos disconnexion." $\mathrm{He}$ divided the fundus of the stomach and resutured it, and also devascularized the upper segment of the stomach and the abdominal part of the oesophagus. No reports of the results of this operation in his hands have been published, but he has said (Tanner, 1958) that he has extended the devascularization further up the oesophagus with early control of bleeding in 11 cases. The experience of Mikkelsen and Pattison (1959) was that bleeding continued of recurred in all their seven patients after this operation.

Habif (1959) has recently reviewed the subject and reports the results in 21 patients upon whom partial oesophago-gastrectomy with jejunal interposition was performed; there were four post- $\exists$ operative deaths. But of the remaining 17 patients, two had bled again, though only four of them had been operated on more than two years previously.

Patients with portal hypertension may go for $10 \frac{\mathrm{O}}{\mathrm{N}}$ years or more between successive episodes of bleed- $\underset{x}{x}$ ing, so that a very long follow-up is required if the $\frac{5}{3}$ results of these procedures are to be evaluated critically. Up to date only small series of any of $\frac{0}{3}$ them have been recorded and in no case have the results over a considerable number of years been given.

In the Department of Surgery of the Bristol Royal Infirmary over the last 10 years a variety of tran- N section operations have been performed in an attempt to control bleeding from oesophageal 0 varices in patients in whom a venous anastomosis $\mathrm{N}$ was considered impractical for one reason or $\overline{2}$ another, and as they have all been closely followedo it is thought worth while to report the indications $\mathbb{\perp}$ and results up to date. As an indication of the $\stackrel{\rho}{?}$ selection of cases during the same period, 140 venous $\frac{T}{-}$ shunts have been performed and the criteria that $\frac{\vec{D}}{\mathbb{D}}$ 
have been adopted for these have already been reported (Walker, 1957). The transections have been performed on the patients rejected for a shunt operation and all who have bled severely have been accepted for operation with the exception of a few who were in terminal liver failure. In many of these cases the time is far too short for a true appraisal of the value of these operations, and the results leave no room for complaisance; but it is to be hoped that others who have been working on this problem will also announce their results so that it may be learned which procedures are of real value to our patients and which are not. In this series the numbers are too small for any statistical analysis. In point of time, the first operation was done in May, 1950, a gastric transection. The first patient to have an oesophageal transection had had two severe haemorrhages and was operated on in September, 1950. A mass of exceedingly vascular adhesions led to the abandonment either of a splenorenal anastomosis (this was before a satisfactory method of performing a portacaval anastomosis had been introduced to the department) or of a gastric transection, so three weeks later, after a further dangerous haemorrhage, transection of the lower end of the oesophagus was performed through the left pleural cavity. That patient has had only one haemorrhage in the nine years since his operation.

There is an argument against transection of the lower end of the oesophagus at the level of the diaphragm that some of these patients have gastric varices, or that they may bleed from the oesophagus below the level of transection. In actual fact fatal bleeding from gastric varices is exceedingly rare, and it is possibly due in part to the difference in pressure above and below the diaphragm that serious bleeding from the oesophagus is nearly always from the thoracic portion. In any case, the results of the various operations must speak for themselves.

\section{TYPE OF OPERATION}

During the 10 years that this survey covers, the present policy in dealing with these patients has gradually evolved. As already mentioned, the first few were operated on before a satisfactory means of performing portacaval anastomoses had been introduced. Until recently a gastric transection has been performed if there have been other reasons for making a laparotomy. Oesophageal transection was avoided in small children as it was feared that a stricture might result, but these fears were probably unfounded; in some cases a gastric transection was made through a thoraco-abdominal approach rather than by laparotomy alone. Nearly half the patients had had a previous splenectomy; in a few of the remainder gastric transection was combined with splenectomy; but if there appeared to be a good collateral circulation around the spleen. which was beneficial, the spleen was left in place, though usually the splenic artery was ligatured in order to reduce the inflow of blood into the portal circulation.

Some years ago it was realized that all the varices in the oesophagus were in the submucous layer, and the only veins in the muscle were perforators; none run for any distance vertically in this layer. Therefore it seemed unnecessary to transect the muscle, so in a group of patients, after incising the muscle longitudinally, only the mucosa and submucosa were divided and resutured. This has been called the mucosal transection to distinguish it from the complete oesophageal transection, and has previously been described (Walker, 1959).

Thus the types of operation which have been performed fall into four main groups: (1) Gastric transection, (2) gastric transection with extensive devascularization, (3) oesophageal transection (complete), and (4) oesophageal transection (mucosal).

\section{Operative Procedures}

(1) Gastric Transection.-This has been performed on 13 occasions, six times by the abdominal and seven by the abdomino-thoracic route (Table I). The operation consisted of the division of the stomach about $5 \mathrm{~cm}$. below the cardia and of all the vascular attachments of the stomach above this level and of the abdominal part of the oesophagus. The stomach was repaired by two layers of continuous catgut. On three occasions the spleen was removed, and in six other cases splenectomy had been done at a previous operation. In one case the splenic artery was ligatured without removal of the spleen. In another case the operation was performed by the abdominal route, and repeated by the thoraco-abdominal approach two and a half years later on account of recurrent bleeding.

(2) Gastric Transection and DevasculariZATION.-This operation is similar to the above, but the freeing of the greater and lesser curvatures of the stomach has been carried down for about half their lengths. It was hoped that by doing this the results might be improved. It has been done seven times, in all except one case by the abdominal route (Table II). In three cases the spleen was removed at the same time, in one the splenic artery was ligatured, and in two an earlier splenectomy had been done.

In one of these cases a transthoracic gastric transection without devascularization had been done five and a half years previously, and two others had had oesophageal transections respectively two and seven and a half years before. 
TABLE I

GASTRIC TRANSECTION

\begin{tabular}{|c|c|c|c|c|c|c|c|c|c|c|c|}
\hline $\begin{array}{l}\text { Case } \\
\text { No. }\end{array}$ & $\underset{\text { tials }}{\text { Ini- }}$ & Sex & $\begin{array}{c}\text { Age at } \\
\text { Time of } \\
\text { First } \\
\text { Haemor- } \\
\text { rhage }\end{array}$ & $\begin{array}{c}\text { Extra- or } \\
\text { Intra- } \\
\text { hepatic } \\
\text { Obstruc- } \\
\text { tion }\end{array}$ & $\begin{array}{l}\text { Previous Operation } \\
\text { and Age }\end{array}$ & $\begin{array}{l}\text { Date of } \\
\text { Tran- } \\
\text { section }\end{array}$ & Age & \multicolumn{3}{|c|}{$\begin{array}{l}\text { Reason for Not } \\
\text { Performing Shunt }\end{array}$} & Result \\
\hline 1 & J.S. & $\mathbf{F}$ & 7 & $\mathbf{E}$ & $\begin{array}{l}\text { Ligature of splenic } \\
\text { artery }-13\end{array}$ & 24.5 .50 & 14 & \multicolumn{3}{|c|}{ No suitable vein } & $\begin{array}{l}\text { Aug., 1951, bled again, splenectomy } \\
\text { performed elsewhere. Sept., 1952, } \\
\text { haemorrhage, second gastric tran- } \\
\text { section (see below) }\end{array}$ \\
\hline 2 & R.S. & $\mathbf{M}$ & 5 & $\mathbf{E}$ & Splenectomy-5 & 12.6 .50 & 9 & & , & , & $\begin{array}{l}\text { Haemorrhages nearly every year. } \\
\text { Died Sept., } 1954\end{array}$ \\
\hline 3 & M.H. & $\mathbf{F}$ & 19 & $\mathbf{I}$ & & 3.7 .50 & 20 & \multicolumn{3}{|c|}{$\begin{array}{l}\text { Before satisfactory } \\
\text { portacaval anasto- } \\
\text { mosis introduced }\end{array}$} & $\begin{array}{l}\text { Dec., 1950, haematemesis. Porta- } \\
\text { caval anastomosis, well since }\end{array}$ \\
\hline 4 & R.G. & $\mathbf{M}$ & 21 & I & $\begin{array}{l}\text { Splenorenal anastomosis } \\
-23\end{array}$ & 25.7 .50 & 26 & & & , & $\begin{array}{l}\text { Slight further bleeding. April, 1954, } \\
\text { gastrectomy for peptic ulcer }\end{array}$ \\
\hline 13 & G.E. & $\mathbf{F}$ & 3 & $\mathbf{E}$ & Splenectomy -4 & 11.8 .52 & 4 & \multicolumn{3}{|c|}{ No suitable vein } & $\begin{array}{l}\text { Dec., 1952, and March, 1953, bleed- } \\
\text { ing. Transpleural ligature of } \\
\text { varices. Oct., 1953, died of } \\
\text { haemorrhage }\end{array}$ \\
\hline 1 & J.S. & $\mathbf{F}$ & 7 & $\mathbf{E}$ & Gastric transection-14 & 2.10 .52 & 16 & , & , & , & $\begin{array}{l}\text { Well till Jan., 1958, then sudden } \\
\text { fatal haemorrhage }\end{array}$ \\
\hline 14 & S.S. & $\mathbf{F}$ & 2 & $\mathbf{E}$ & Splenectomy-3 & 16.9 .52 & 5 & , & ," & , & $\begin{array}{l}\text { Aug., 1954, and July, 1956, bleed- } \\
\text { ing. Sept., 1956, oesophageal } \\
\text { transection }\end{array}$ \\
\hline 15 & M.F. & $\mathbf{F}$ & 1 & $\mathbf{E}$ & , $\quad-6$ & 9.10 .52 & 8 & , & ", & , , & $\begin{array}{l}\text { Repeated haemorrhages. Died } \\
\text { Sept., } 1957\end{array}$ \\
\hline 16 & E.W. & $\mathbf{M}$ & 9 & $\mathbf{E}$ & $\begin{array}{l}\text { Splenorenal anastomosis } \\
-10\end{array}$ & 27.1.53 & 14 & , & , & , & $\begin{array}{l}\text { Repeated haemorrhages. } \\
\text { 1958, gastric transection with } \\
\text { devascularization }\end{array}$ \\
\hline 20 & M.B. & $\mathbf{F}$ & 32 & I & & 27.5 .54 & 34 & , & , & , & $\begin{array}{l}\text { Jan., 1955, haemorrhage. Subse- } \\
\text { quent oesophago-gastrectomy else- } \\
\text { where, slight bleeding since }\end{array}$ \\
\hline 31 & C.K. & $\mathbf{F}$ & 4 & $\mathbf{E}$ & & 24.1 .57 & 5 & , &, & , & $\begin{array}{l}\text { Nov., } 1957 \text {, haematemesis, further } \\
\text { slight bleeding. Aug., 1959, } \\
\text { varices still present }\end{array}$ \\
\hline 34 & E.S. & $\mathbf{F}$ & 57 & I & & 22.7.57 & 57 & Pre & ious & cepha- & $\begin{array}{l}\text { Sept., 1957, and Oct., } 1958 \text { Q } \\
\text { haemorrhages }\end{array}$ \\
\hline 36 & W.A. & $\mathbf{M}$ & 45 & $\mathbf{E}$ & & 17.9 .57 & 45 & & uital & vein & 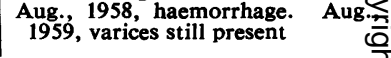 \\
\hline
\end{tabular}

TABLE II

GASTRIC TRANSECTION WITH DEVASCULARIZATION

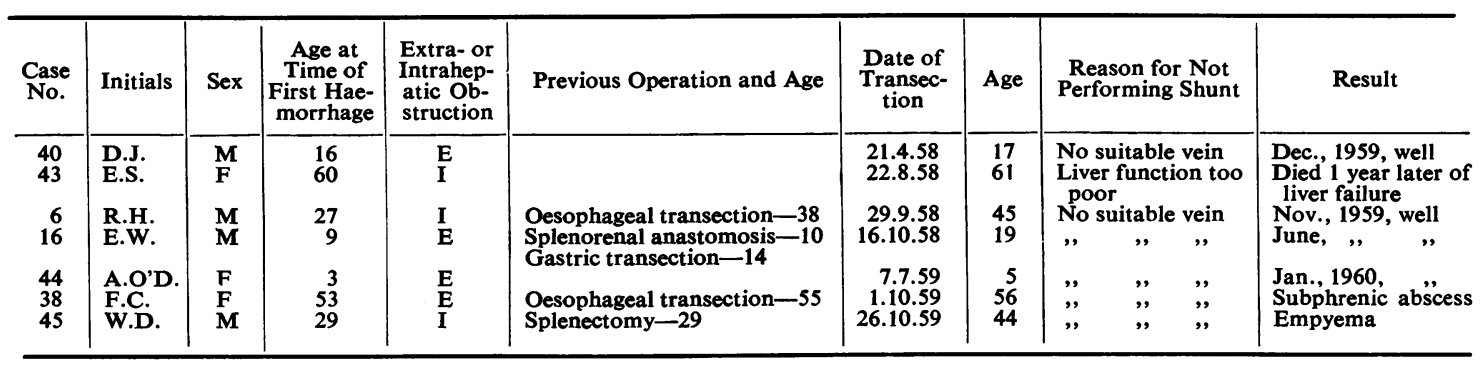

(3) Oesophageal Transection (Complete).The oesophageal transections (Table III) have all been performed by an approach through the bed of the seventh or eighth rib and the left pleural cavity. The lower portion of the thoracic oesophagus is lifted from its bed and a tape passed round it. Any large veins draining the segment are divided. The vagus nerves are dissected free and by drawing on the tape the abdominal part of the oesophagus can be pulled up so that a light clamp can be placed on it at the level of the hiatus. It is now considered important that the abdominal oesophagus be pulled up so that eventually the line of section and resuture will lie at the level of the hiatus. The oesophagus is then divided across a little way above the clamp and $N$ repaired with a single layer of continuous catgut $N$ sutures. After removal of the clamp bleeding points on the wall are underrun with catgut stitches; a $\omega$ small gastric tube is then passed from the mouth down into the stomach, and the chest is closed leaving a sealed drainage tube in the pleural cavity.

This operation has been done 18 times, four times as an emergency operation for uncontrolled bleeding when the liver function has been poor. 
TABLE III

OESOPHAGEAL TRANSECTION (COMPLETE)

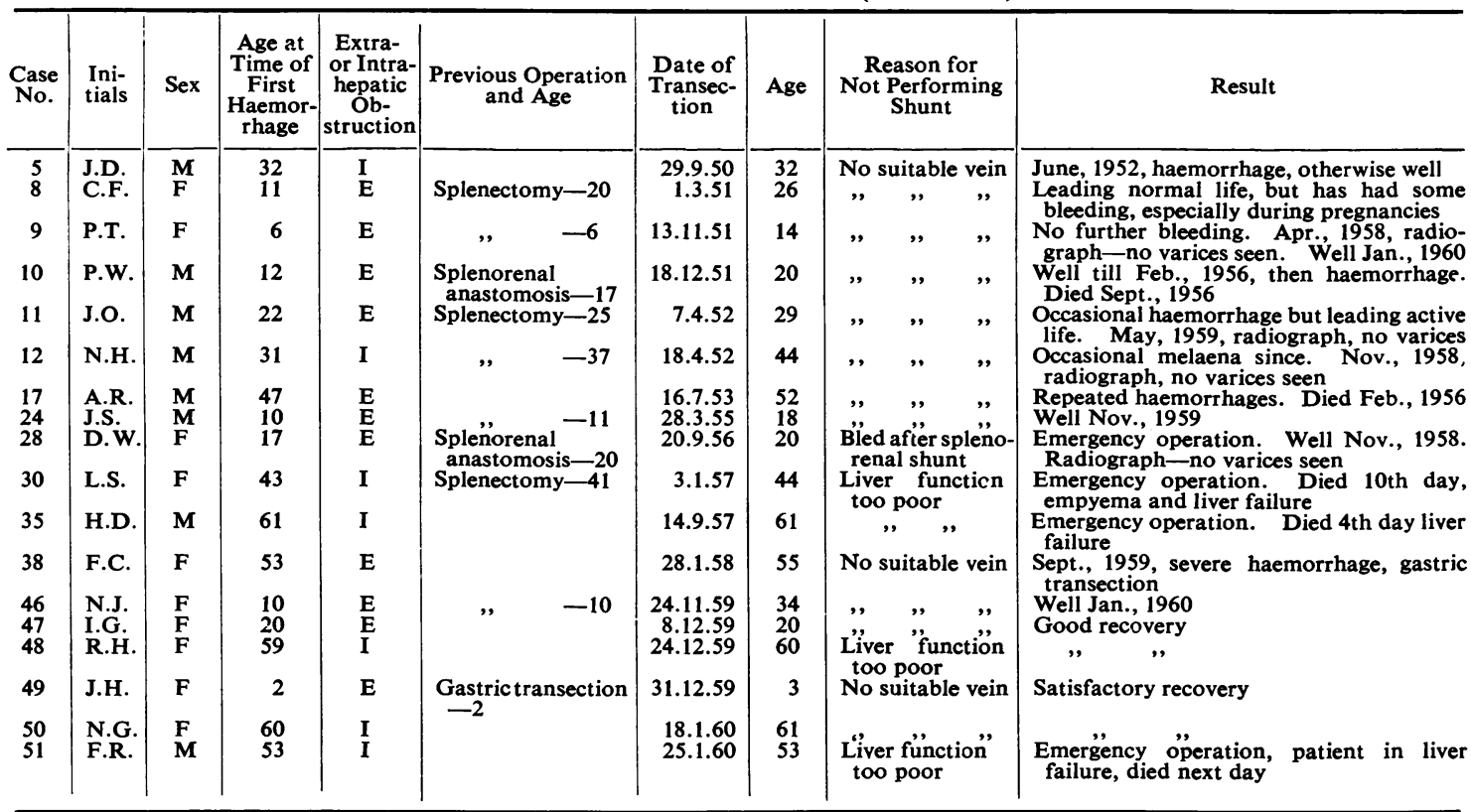

TABLE IV

OESOPHAGEAL TRANSECTION (MUCOSAL)

\begin{tabular}{|c|c|c|c|c|c|c|c|c|c|}
\hline $\begin{array}{l}\text { Case } \\
\text { No. }\end{array}$ & $\begin{array}{l}\text { Ini- } \\
\text { tials }\end{array}$ & Sex & $\begin{array}{c}\text { Age at } \\
\text { Time of } \\
\text { First } \\
\text { Haemor- } \\
\text { rhage }\end{array}$ & $\begin{array}{c}\text { Extra- } \\
\text { or Intra- } \\
\text { hepatic } \\
\text { Ob- } \\
\text { struction }\end{array}$ & $\begin{array}{c}\text { Previous Operation } \\
\text { and Age }\end{array}$ & $\begin{array}{l}\text { Date of } \\
\text { Tran- } \\
\text { section }\end{array}$ & Age & $\begin{array}{l}\text { Reason for } \\
\text { Not Performing } \\
\text { Shunt }\end{array}$ & Result \\
\hline 6 & R.H. & $\mathbf{M}$ & 27 & I & $\begin{array}{l}\text { Splenic artery liga- } \\
\text { ture }-36\end{array}$ & 29.1 .51 & 38 & No suitable vein & $\begin{array}{l}\text { Well till Jan., 1958, then large haemor- } \\
\text { rhage, subsequent gastric transection }\end{array}$ \\
\hline 7 & J.P. & $\mathbf{M}$ & 29 & $\mathbf{I}$ & $\begin{array}{l}\text { Splenorenal anas- } \\
\text { tomosis-31 }\end{array}$ & 5.2 .51 & 33 & $\begin{array}{c}\text { Failed spleno- } \\
\text { renal anasto- } \\
\text { mosis }\end{array}$ & $\begin{array}{l}\text { Nov., 1951, haematemesis. Jan., 1952, } \\
\text { portacaval anastomosis. } \\
\text { died haemorrhage }\end{array}$ \\
\hline 18 & R.L. & $\mathbf{M}$ & 23 & $\mathbf{I}$ & $\begin{array}{l}\text { Splenectomy-26 } \\
\text { Portacaval anasto- } \\
\text { mosis }-29\end{array}$ & 26.10 .53 & 31 & $\begin{array}{l}\text { Bleeding after } \\
\text { portacaval } \\
\text { anastomosis }\end{array}$ & $\begin{array}{l}\text { Occasional melaena since. Jan., 1958, } \\
\text { duodenal ulcer. Dec., 1959, well }\end{array}$ \\
\hline 19 & W.P. & $\mathbf{M}$ & 20 & I & $\begin{array}{l}\text { Splenectomy-21 } \\
\text { Portacaval anasto- } \\
\text { mosis-30 }\end{array}$ & 19.11 .53 & 31 & ", & Very well since \\
\hline $\begin{array}{l}21 \\
22\end{array}$ & $\begin{array}{l}\text { S.T. } \\
\text { A. } \\
\text { McC. }\end{array}$ & $\begin{array}{l}\mathbf{F} \\
\mathbf{F}\end{array}$ & $\begin{array}{r}33 \\
4\end{array}$ & $\mathbf{I}$ & $\begin{array}{l}\text { Splenectomy-34 } \\
\text { Splenorenal anas- } \\
\text { tomosis-7 }\end{array}$ & $\begin{array}{l}25.10 .54 \\
18.11 .54\end{array}$ & $\begin{array}{l}39 \\
12\end{array}$ & $\begin{array}{l}\text { Jaundice } \\
\text { No suitable vein }\end{array}$ & $\begin{array}{l}\text { Sept., } 1959 \text {, well } \\
\text { No further bleeding. Radiograph Sept., } \\
1959 \text {, no varices }\end{array}$ \\
\hline 23 & & $\mathbf{M}$ & 10 & $\mathbf{E}$ & $\begin{array}{l}\text { Splenorenal anas- } \\
\text { tomosis-10 }\end{array}$ & 22.3 .55 & 11 & , , , , , & Jan., 1960, well \\
\hline 25 & M.W. & $\mathbf{F}$ & 54 & I & & 13.8 .55 & 55 & $\begin{array}{l}\text { Liver function } \\
\text { too poor }\end{array}$ & $\begin{array}{l}\text { Slight occasional bleeding. July, } 1959 \text {, } \\
\text { died, liver failure }\end{array}$ \\
\hline 26 & F.H. & $\mathbf{F}$ & 54 & $\mathbf{I}$ & & 29.9 .55 & 55 & $\begin{array}{l}\text { Previous } \\
\text { encephalopathy }\end{array}$ & Aug., 1956, haemorrhage, hepatic coma, \\
\hline 27 & S.S. & $\mathbf{F}$ & 23 & $\mathbf{E}$ & & 30.8 .56 & 23 & No suitable vein & Well Jan., 1960 \\
\hline 14 & S.S. & $\mathbf{F}$ & 2 & $\mathbf{E}$ & $\begin{array}{l}\text { Splenectomy-3 } \\
\text { Gastric tran- }\end{array}$ & 3.9 .56 & 9 & , , , , , & Mar., 1959, slight melaena \\
\hline 29 & K.W. & $\mathbf{F}$ & 54 & I & section-5 & 12.11.56 & 54 & $\begin{array}{l}\text { Liver function } \\
\text { too poor }\end{array}$ & $\begin{array}{l}\text { Emergency operation. Died 2nd day liver } \\
\text { failure }\end{array}$ \\
\hline $\begin{array}{l}32 \\
33\end{array}$ & $\begin{array}{l}\text { E.V. } \\
\text { K.M }\end{array}$ & $\begin{array}{l}\mathbf{F} \\
\mathbf{F}\end{array}$ & $\begin{array}{r}63 \\
4\end{array}$ & $\mathbf{I}$ & Splenectomy -4 & $\begin{array}{l}4.7 .57 \\
9.7 .57\end{array}$ & $\begin{array}{l}64 \\
17\end{array}$ & $\begin{array}{l}\text { Age } \\
\text { No suitable vein }\end{array}$ & $\begin{array}{l}\text { Died 6th day bronchopneumonia } \\
\text { Well Dec., } 1959\end{array}$ \\
\hline 37 & M.E. & $\mathbf{F}$ & 47 & I & & 27.1 .58 & 53 & , , , , & $\begin{array}{l}\text { Dec., 1959, very well. Radiograph slight } \\
\text { varices }\end{array}$ \\
\hline 39 & T.M. & $\mathbf{M}$ & 14 & $\mathbf{E}$ & $\begin{array}{l}\text { Splenectomy and } \\
\text { gastric tran- } \\
\text { section-14 }\end{array}$ & 10.2 .58 & 15 & , & Jan., 1960, very well \\
\hline 41 & G.M. & $\mathbf{F}$ & 59 & I & & 16.6 .58 & 59 & $\begin{array}{l}\text { Liver function } \\
\text { too poor }\end{array}$ & Well Jan., 1960 \\
\hline 42 & A.C. & $\mathbf{F}$ & 70 & I & & 19.6.58 & 72 & $\begin{array}{l}\text { Age: liver func- } \\
\text { tion too poor }\end{array}$ & Well Oct., 1959 \\
\hline
\end{tabular}


(4) Oesophageal Transection (Mucosal).-The steps of this operation are the same as those for complete transection until the oesophagus has been freed, but it is unnecessary to dissect out the vagus nerves. After the clamp has been placed on the lower end, the muscle is incised vertically for about $5 \mathrm{~cm}$. and the mucosal core, which is only loosely attached to the muscle, can then be lifted out of its muscular tube with very little light dissection; this mucosal tube is then cut across and resutured with continuous catgut. The clamp is released, any bleeding veins underrun, and the muscle drawn together with a few interrupted catgut stitches.

This type of operation has been done on 18 occasions (Table IV) in this series; in one case the diaphragm was incised and the spleen removed. One case was an emergency procedure.

During the operation of oesophageal transection the diaphragm has sometimes been incised in order to make a recording of the portal pressure, and to examine the liver and take a specimen for biopsy. It might be pointed out here that palpation of the right free margin of the lesser omentum can be deceptive regarding the patency of the portal vein and no reliance can be placed on such an examination; venography is the only means, apart from direct exposure, of determining its state.

\section{INDICATIONS FOR TRANSECTION OPERATIONS}

The only known way of bringing down the portai blood pressure is a wide portal systemic venous anastomosis, and this is the best method of preventing bleeding from oesophageal varices. Transection operations are palliative in that they do nothing to lower the portal blood pressure.

The cases fall into two groups: those with primary extrahepatic obstruction, and those with liver disease causing intrahepatic obstruction, though some of this group may have secondary thrombosis of the portal vein and thus an added extrahepatic obstruction.

In the majority of patients who have primary extrahepatic obstruction no definite aetiological factor can be recognized. In six, however, there was an illness which was probably significant in causing portal vein thrombosis, as set out below:

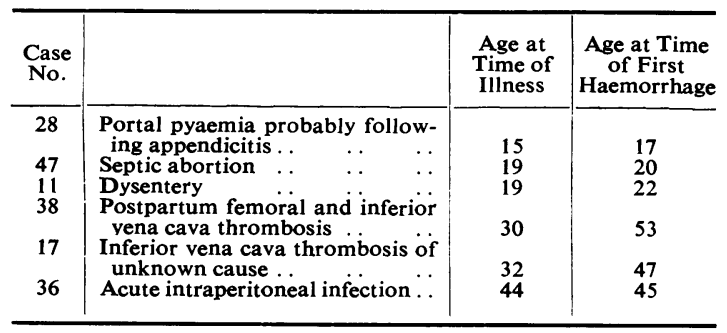

In two patients with thrombosis of the inferior vena cava the long interval between this and the first haemorrhage suggests that the portal vein thrombosis did not occur at the time of the caval thrombosis, but that these patients had a general predisposition to intravascular clotting. In all the remaining 20 patients with primary extrahepatic obstruction, bleeding started between the ages of 1 year and 23 years, with an average age of 7.8 years. It may be surmised that the cause was a spread of thrombosis from the umbilicus to the portal vein, possibly infective in origin; in fact two patients had acute suppurative arthritis and two had osteomyelitis during the neonatal period. All these patients retained normal liver function. Thus the only reason for not performing a portal systemic anastomosis was that there was no suitable vein available. In all the portal vein was thrombosed and replaced by collateral channels; in some the splenic vein was also thrombosed, in others it was considered too small for a satisfactory anastomosis. Sixteen had already had the spleen removed, thus making the splenic vein no longer available for a splenorenal anastomosis.

There was a greater variety of reasons for not making a venous shunt in the patients with intrahepatic obstruction, for here the hazards of liver failure are added to those of the haemorrhage, and some patients were on the verge of failure at the time, but conservative measures had not controlled the bleeding. The reasons were as follows:

(1) There was no suitable vein for a portal-systemic anastomosis. This was the reason in eight cases owing to secondary thrombosis in the portal system. There may have been added extrahepatic obstruction in other cases because venography was not done on some of the patients who were unsuitable for a shunt for other reasons.

(2) Liver function was considered too poor for a venous anastomosis; the presence of jaundice, or a serum albumin level below $3 \mathrm{~g} . \%$, have generally been regarded as contraindications to a shunt operation. This applied to 11 patients, four of whom were operated on as emergencies.

(3) Two patients had gastric transections in 1950 before a satisfactory technique for portacaval anastomosis had been introduced to the department.

(4) Two patients who bled after portacaval anastomosis have had oesophageal transections.

(5) Two patients were considered too old for portacaval anastomosis, and in one of these the liver function was unsatisfactory.

\section{RESULTS}

Owing to the varying length of time and the small number of cases it is very difficult to assess the 
results; the sole object of the operation has been to prevent haemorrhage; this must be the criterion, but some patients inevitably die of liver failure during the follow-up period. In addition some have had repeated bleedings at short intervals before their operation, whereas others have had perhaps only one bleeding, albeit a serious one, but might go for several years before their next, and conceivably might never have another in the natural course of events. Thus one survived five and a quarter years after a second transection operation without bleeding during this time and then died of a massive haemorrhage.

Details of each case are set out in Tables I to IV, and Table $\mathrm{V}$ summarizes the type and number of operations performed and the average time of follow-up or to death.

TABLE V

SUMMARY OF RESULTS*

\begin{tabular}{|c|c|c|c|c|c|c|c|}
\hline \multirow{3}{*}{ Type of Operation } & \multirow{3}{*}{$\begin{array}{l}\text { No. of } \\
\text { Cases }\end{array}$} & \multirow{2}{*}{\multicolumn{2}{|c|}{ Dead }} & \multicolumn{4}{|c|}{ Survivors } \\
\hline & & & & \multicolumn{2}{|c|}{ Bled Again } & \multicolumn{2}{|c|}{ No Bleeding } \\
\hline & & No. & $\mid \begin{array}{c}\text { Average } \\
\text { Time } \\
\text { (Yr.) }\end{array}$ & No. & $\mid \begin{array}{c}\text { Average } \\
\text { Time } \\
\text { (Yr.) }\end{array}$ & No. & $\begin{array}{c}\text { Average } \\
\text { Time } \\
\text { (Yr.) }\end{array}$ \\
\hline \multicolumn{8}{|c|}{ Extrahepatic Obstruction } \\
\hline \multirow{2}{*}{$\begin{array}{l}\text { Gastric transection } \\
\text { Gastric transection + } \\
\text { devascularization } \\
\text { Oesophageal tran- } \\
\text { section (complete) } \\
\text { Oesophageal tran- } \\
\text { section (mucosal) }\end{array}$} & $\begin{array}{l}9 \\
3\end{array}$ & 5 & $4 \frac{1}{2}$ & $4 \dagger$ & $4 \frac{1}{2}$ & 3 & 1 \\
\hline & 8 & 2 & $3 \frac{1}{2}$ & $3 \ddagger$ & 6 & 3 & \\
\hline \multirow{4}{*}{$\begin{array}{l}\text { Intrahepatic Obstructi } \\
\text { Gastric transection } \\
\text { Gastric transection + } \\
\text { devascularization } \\
\text { Oesophageal tran- } \\
\text { section (complete) } \\
\text { Oesophageal tran- } \\
\text { section (mucosal) }\end{array}$} & $\begin{array}{l}\text { ion } \\
4\end{array}$ & & & $4 \S$ & $6 \frac{1}{2}$ & & $\sqrt{2}$ \\
\hline & 2 & 1 & 1 & & & 1 & 1 \\
\hline & 2 & & & 2 & 8 & & \\
\hline & 10 & 3 & 2 & $2 \|$ & $7 \frac{1}{2}$ & 5 & 3 \\
\hline
\end{tabular}

* Excluding patients operated on less than six months ago and five patients who died while still in hospital. + Two have had later operation. ‡ One has had a further operation. § Three have had later operation. "I One has had a further operation.

\section{Discussion}

The outlook for patients who bleed from oesophageal varices and who have no wide vessel in their portal venous system which can be used for an anastomosis is indeed serious. Particularly disturbing are the cases of the younger patients who have primary extrahepatic obstruction, for they are very likely to bleed to death, yet they retain normal liver function. The earlier in life that bleeding starts, the poorer is their chance of survival to adult life. The gloomy story related here is only portrayed by a long-term follow up, for between the bouts of haemorrhage these patients usually feel perfectly well, and they may be considered to be out of danger. Of 29 patients with primary extrahepatic obstruction who had their first haemorrhage under the age of 20 years (19 of whom are in this series), eight are known to have died of haemorrhage any time up to 15 years after their first attack of bleeding. The details of this group will be published elsewhere.

Any steps which can reduce this danger without undue operative risk are worth while, for there is always the chance that collateral vessels which are not dangerous will open up at other sites. In this review the results of one type of operation have been considered. Gastric transections without extensive devascularization of the stomach have given disappointing results, and should be abandoned. It is too early to assess the long-term results of this transection when combined with devascularization of the upper half of the stomach, but in the seven cases in which it has been done, subphrenic abscesses in two with a temporary fistula in one have complicated recovery. Oesophageal transection has proved to be more effective in diminishing the danger of further haemorrhage. It is not a difficult operation. The operative mortality has been small, five cases among 36 operations, four of these following emergency operations while the patient was bleeding and already in liver failure; three died of liver failure, one of bronchopneumonia (a patient of 64), and one of an empyema in a patient with poor liver function. Empyema complicated two of the other operations in patients who recovered; otherwise there were no serious complications to the operation.

As far as the results indicate it does not seem to matter much whether the whole oesophagus is transected, or only the mucosa and submucosa.

In a few cases the results have been dramatic in the control of haemorrhage. Three examples of primary extrahepatic obstruction are:

CASE 9.-P.T. had haematemesis in 1943 at the age of 6 and following this her spleen was removed; haemorrhage recurred in May, 1945, in January a nd August, 1946, in 1948, in March, 1949, and in October, 1951. After oesophageal transection in November, 1951, she has had no further haemorrhage; in 1958 no varices could be detected radiologically: she remains well in January, 1960.

CASE 24.-J. S. had his first haemorrhage in 1947 at the age of 10, and after bleeding in 1948 his spleen was removed. Haematemesis recurred nearly every year and by 1955 he had had nine blood transfusions; there has been no further bleeding in the four and a half years since oesophageal transection.

CASE 39-T.M. had two severe haematemeses at the age of 14 in October, 1957. At a laparotomy the liver was found to be normal, the portal pressure $28 \mathrm{~mm}$. $\mathrm{Hg}$, and the spleen enlarged. A gastric transection and removal of the spleen were performed, but bleeding continued and was controlled by a cuffed oesophageal tube. Three 


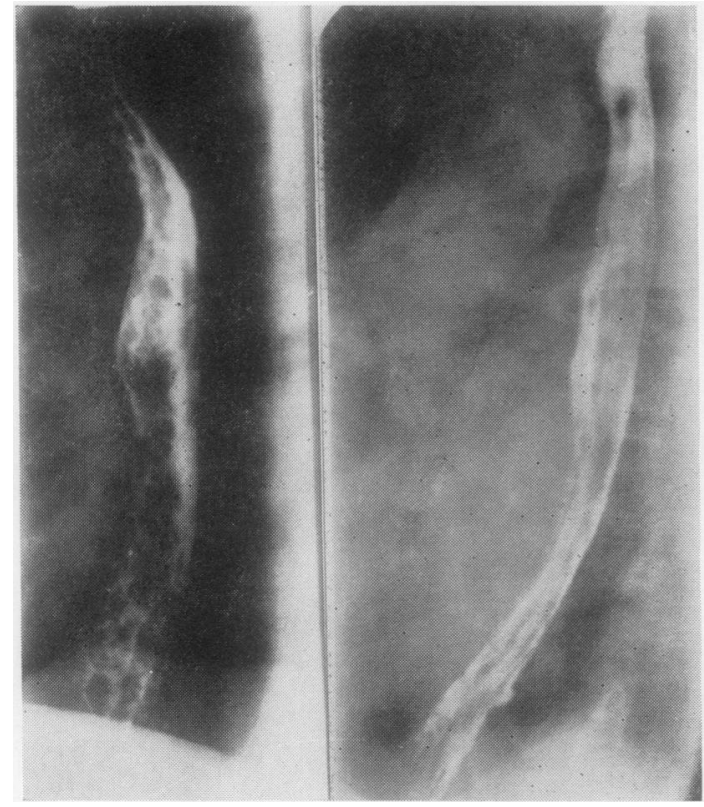

FIG. 1.-Radiographs after barium swallow before and two years after oesophageal mucosal transection. Radiographs by courtesy of Dr. T. N. Fogarty, Lurgan, N. Ireland.

months later he was transferred to Bristol and a mucosal oesophageal transection performed. Since then he has remained in excellent health (Fig. 1).

Examples of intrahepatic obstruction are:

CASE 5.-This man, J.D., had hepatitis with jaundice in 1943. In 1950, at the aged of 32 , he had within a month two severe haematemeses requiring transfusion of 5 litres of blood. Laparotomy revealed a firm nodular liver and a portal pressure of $35 \mathrm{~mm}$. $\mathrm{Hg}$ and thrombosed portal and splenic veins. A week later he had a further haemorrhage necessitating transfusion of 4 litres of blood; oesophageal transection was carried out. He had in 1952 a further haemorrhage not requiring transfusion, but this is the only episode during the nine and a half years since his operation.

CASE 37.-M.E., a woman of 53, had had 10 haemorrhages which required transfusion between 1952 and 1958; she has cirrhosis with thrombosis of the portal and splenic veins; in the two years since oesophageal transection she has had no further bleeding.

CASE 42.-A.C. had a cholecystectomy in 1954, and a choledochoduodenostomy for a stricture of the lower end of the common bile duct in 1955. Haematemeses began in 1956 and recurred eight times in two years. In 1958, at the age of 72 , an oesophageal transection was performed and bleeding has not recurred in the subsequent one and a half years.

It will be appreciated on looking at the case lists that the above-quoted results are exceptional, but they indicate that a relatively simple operation can do much to reduce the danger of haemorrhage. This operation is applicable at all ages and the present series covers a range from 3 to 72 years. At the present time we consider that oesophageal transection offers the best prospect of freedom from further haemorrhage in cases of portal hypertension in which a wide portacaval or splenorenal anastomosis is inadvisable because the liver function is too poor, or impossible because there is no suitable vein. The transection should be at the level of the hiatus. This is the crucial area where there is a sudden drop from the intra-abdominal to the intrathoracic pressure. Operations which leave a part of the alimentary canal passing through this hiatus without interference with the blood vessels in its wall seem destined to leave the way open for varices to re-form.

\section{SUMMARY}

Measures are recorded which have been used to prevent haemorrhage from oesophageal varices in patients when conditions are unsuitable for a portal systemic venous anastomosis.

Over a period of nine and a half years various types of transection operation have been employed at the Bristol Royal Infirmary. Fifty-six of these operations have been done on 51 patients. The techniques are briefly described and the results given Long-term follow-up is essential, and all patients have so been followed up. Lower oesophageal transection has given better results than gastric transection. Though the results are far from satisfactory they are probably as good as those obtained by other methods, some of which carry a much greater operative risk.

My thanks are due to Mr. P. J. Monks, who has helped with the follow-up, and to all those members of the medical and nursing staffs of the United Bristol Hospitals who have co-operated in the treatment.

\section{REFERENCES}

Allison, P. R. (1959). Ann. roy. Coll. Surg. Engl., 25, 298.

Blackburn, C. R. B. (1956). Thorax, 11, 30.

Boerema, I. (1949). Arch. Chir. Neerland., 1, 253.

Clatworthy, H. W., and Boles, E. T: (1959). Ann. Surg., 150, 371. Cooley, D. A., and DeBakey, M. E. (1954). A.M.A. Arch. Surg. 68,854

Crile, G. (1957). Surgery, 42, 583

Habif, D. V. (1959). Ibid., 46, 212

Koop, C. E., and Roddy, S. R. (1958). Ann. Surg., 147, 17.

Koop, C. E., and Roddy, S. R. (1958). Ann. Surg., 147, 17. Macbeth, R. (1955). Brit. med. J., 2, 877. Amer. med. Ass., 160, 1017. Macbeth, R. (1955). Brit. med. J., 2, 877 . 353.

Merendino, K. A., and Thomas, G. I. (1958). Surgery, 44, 1112.

Mikkelsen, W. P., and Pattison, A. C. (1959). Ibid., 46, 501

Nylander, P. E. A., and Turunen, M. (1955). Ann. Surg., 142, 954

Phemister, D. B., and Humphreys, E. M. (1947). Ibid., 126, 397

Tanner, N. C. (1950). Proc. roy. Soc. Med., 43, 147.

(1958). Ann. roy. Coll. Surg. Engl., 22, 30

Walker, R. M. (1957). Lancet, 1, 57.

(1959). The Pathology and Management of Portal Hypertension, p. 83. Arnold, London.

Welch, C. S. (1956). New Engl. J. Med., 255, 677 